\title{
FACTORS AFFECTING FRANCHISING DEVELOPMENT IN THE ECONOMY OF THE EUROPEAN COUNTRIES
}

\author{
Iryna Prykhodko', Solomiya Ohinok ${ }^{2}$
}

\begin{abstract}
The purpose of the study is to distinguish and analyze the factors that influence the development of franchising in the globalized system of world economic relations. The usage of franchising as a mechanism to activate the innovative activity in Ukraine will increase the effectiveness of innovation introduction in the economy. Methodology. The research is based on the scientific works and researches of domestic and foreign scientific. The methodological grounds for the study are general scientific and special-scientific methods, knowledge. The comparative method was used to compare the growth rate of franchising in different countries. The statistical method was used to establish data that shows franchising development in different economies. The interpretation was used to explain the results of the empirical study. The method of grouping and classifying was used to characterize the ratio of the leading industries in using franchising and types of franchises. Abstract-logical and graphic interpretation was used in the study of peculiarities of franchising development strategies. Method of analysis and synthesis helped to formulate conclusions. Results. A franchise form of business activity organization will enhance the efficiency of the Ukrainian economy and increase the competitiveness of national products in the European market, therefore the franchising strategies of European companies' entry on the Ukrainian market were analyzed. In the context of integration, the efficacy of the franchise tool for business in Ukraine was proven. Practical implications. The study is devoted to a detailed analysis of how the network age affects the franchisor's network size, and it is proven that the older the franchisor is, the more franchise points it has. It is analyzed that with the increase of all these indicators, the network size grows, and the percentage of own points has a little effect; a franchise fee also increases according to the franchise network size; the amount of royalty depends on the investment level and the franchise network size. Value/originality is the theoretical and empirical study of factors influencing the development of franchising. The highlighted positions can be used for further study of franchise development.
\end{abstract}

Key words: franchising, franchisor, franchisee, franchise fee, royalty, franchise outlets.

JEL Classification: F23, M21

\section{Introduction}

The modern world economy is characterized by a high degree of globalization and the integration of not only economic life but also the problems of mankind closely related to it. Since national boundaries are becoming less important, the distinction between countries' economies is eroded, and internationalization and transnationalization contribute to the convergence of national economies, the formation of economic unions and single economic space; among global challenges, there is environmental degradation, which is under a strong influence of devastating economic activity, is of the central importance. One of the effective instruments for the transition to states' innovative development,

\footnotetext{
Corresponding author:

${ }^{1}$ Ivan Franko National University of Lviv, Ukraine.

E-mail: iryna.prykhodko2015@gmail.com

ORCID: http://orcid.org/0000-0002-3366-1185

ResearcherID: V-6261-2017

${ }^{2}$ Ivan Franko National University of Lviv, Ukraine.

E-mail: ohinok.solomiya@gmail.com

ORCID: http://orcid.org/0000-0001-5462-5362
}

therefore, to ensuring their sustainable development is franchising, which promotes the strengthening of economic ties between countries at the present stage of the development of world economic relations, penetrates virtually all spheres of economic activity and is one of the most effective and democratic ways to go beyond national markets. Franchising favours the strengthening of economic relations between countries at this stage of their development, as today it is involved in almost all areas of economic activity and is one of the most effective and democratic ways of transcending national markets. Due to the above, the issue is relevant to the study. Although franchising is considered to be a relatively new kind of activity arrangement, it is 
a dominant form of doing business both in the United States and Europe, and its growth rate becomes more and more significant every year.

In terms of international and continental integration, the issue of increasing the number of small and medium-sized enterprises offering their products under certain conditions becomes especially important. At the stage of the development of world economic relations, franchising facilitates to strengthen economic ties between countries and has penetrated almost all economic activity spheres; it is one of the effective and democratic ways of going beyond national markets.

Under modern conditions of market fierce competition, low awareness and relatively limited financial capacities, franchising is a powerful and effective tool to address these issues. It is well known that franchising promotes the business, becomes more informed, and it also weakens fierce competition in a particular segment of the market. This phenomenon can be explained by the fact that the market economy is mainly formed by large enterprises and small and medium businesses. The first ones can stabilize the economy and influence the development of scientific and technological progress, and small and mediumsized enterprises are quite mobile and able to form a competitive environment.

\section{Analysis of recent research and publications}

The principles of the scientific substantiation of franchising as a progressive method of business were laid down by G. J. Bolt, Yu. Bondarenko, J. Evans, B. Karloff, D. Kaufman, J. Kornai, J. Stiglitz, enhanced and complemented by M. Woodrow, V. Dovhan, D. Klein, R. Martin, M. Mandelson, A. Minkler, D. North, I. Rykova, J. Fielding, J. Henson and others.

A significant contribution to the franchising issue development was made by the following Ukrainian scientists: O. Kuzmin, D. Baiura, O. Bilorus, V. Budkin, I. Burakovskyi, L. Halperina, N. Hrushchynska, M. Dudchenko, N. Komar, A. Kredisov, D. Lukianenko, V. Novytskyi, Ye. Panchenko, Yu. Pakhomov, O. Plotnikov, A. Poruchnyk, A. Rumiantsev, S. Sidenko, Yu. Spektorov, O. Trushenko, A. Filipenko, Yu. Fedun and others. The principles of ecological franchising are substantiated in the papers of I. Illiashenko.

Therefore, the main purpose of this study is to distinguish and analyze the factors that influence the development of franchising in the globalized system of world economic relations. The urgency of the study is intensified in the context of the recent appearance of franchising in general and in the Ukrainian market; an insufficient number of researches on the mentioned topic of domestic scientists and the need to increase the economic potential of our state as soon as possible to ensure a decent position in the world market.

\section{Franchising as a special form of business organization in European countries}

Franchising as one of the most popular ways to conduct and expand business provides both parties of a franchise contract with undeniable advantages. A franchise strategy is the fastest and easiest way to penetrate foreign markets. The role of a franchise strategy as an instrument of sales network expansion is growing, since an increase in the number of franchise points contributes to the company's rapid development. Franchising is a product of intellectual property, which is realized at the expense of domestic investors and allows enterprises to create a network with a single brand name inside and outside the European Union.

Franchising is popular because it creates favorable conditions for expanding networks for goods sales both in domestic and foreign markets and allows raising the number of missions in a short time and at a low cost. If franchising business is developing within a country, it means the attraction of foreign direct investment that meets the needs of businesses for limited resources and allows them to improve the quality of their products and increase competitiveness in general.

Franchising is recognized in the world as the most progressive form of doing business. Franchising attractiveness is determined primarily by its transparency and complexity. Such a business strategy offers great prospects, since it enables to attract foreign investment from different countries to develop one industry, as well as to implement high standards (Stawicka, 2009).

The role of franchising in Europe is growing every year, as on the basis of the single European market membercountries have received significant benefits connected with the intensification of international production and promotion of small and large companies.

Analyzing the dynamics of the growth of franchises in Europe, one can see that in each country it is different and it is not surprising, because there are countries such as Great Britain, France, Italy, Belgium for which franchising is not a new phenomenon but fairly highly developed and widespread, whereas for example in Poland, it has gained great popularity only in recent years. According to the Report on the franchise market in Poland, which was prepared by the company PROFIT system, the dynamics of the number of franchise outlets over the past 10 years has been continuously growing. In previous years the Polish franchise market was mainly represented by franchise systems belonging to catering, but now the development of concepts in the service field has accelerated that significantly brings Poland to the highest European standards, which are characteristic of European markets (European Franchise Federation, 2019).

Considering the leading industries in Europe with the use of franchising in general, then their ratio can be defined as follows: fast food restaurants $-53 \%$; hotel business $-14 \%$; full service restaurants $-11 \%$; service sector $-8 \%$; retail trade $-6 \%$ (Figure 1 ). 


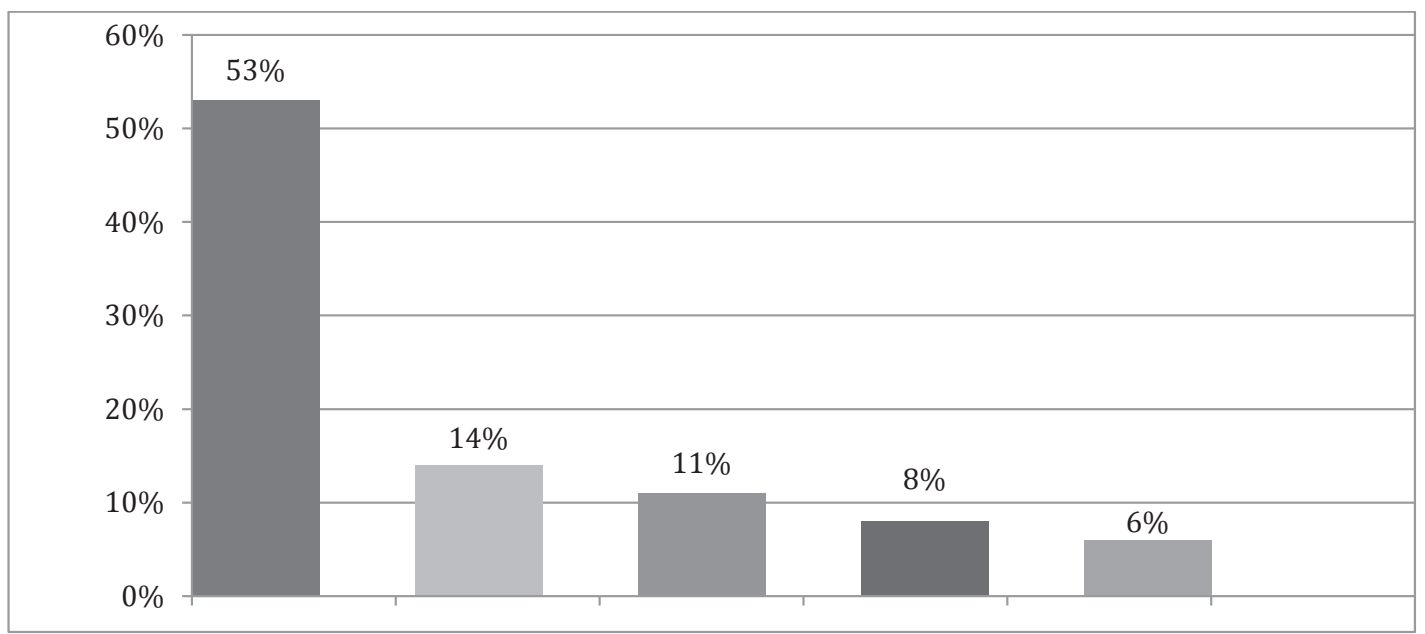

Figure 1. The ratio of the leading industries in using franchising in Europe

Source: International Franchising: The European Union, 2018

The country's acquisition of the membership in the EU promotes the spread of franchising as a tool to increase the number of goods sales networks, as it is the opportunity for national firms to enter large and small foreign markets (Figure 2).

It is worth noting that the franchise European market stands out for its special features and is disposed to such trends as:

- the increase in franchise subsections within the network that is an increasing number of franchisees are trying to open as many outlets of their franchisors as possible;

- the internationalization of European franchising is enhanced, it is promoted not only by transcending the country of origin by a certain franchise network, but also by the membership in the European Union;
- increased usage of new technologies;

- the establishment of franchise associations in each country of Europe.

Comparing the dynamics of the number of franchise outlets in Ukraine and Poland, one can see that franchising is developing much more slowly in our country despite the fact that over the last eight years in our country there has been the positive dynamics of the development of franchise networks.

The franchising market in Ukraine is presented mainly by brands of national origin; however, European franchise networks occupy $24 \%$ of the market.

In the conditions of low innovation activity of our state, it is important to use franchising, which acts as one of the forms of financing high-tech activities. Adopting the experience of European countries, Ukraine will

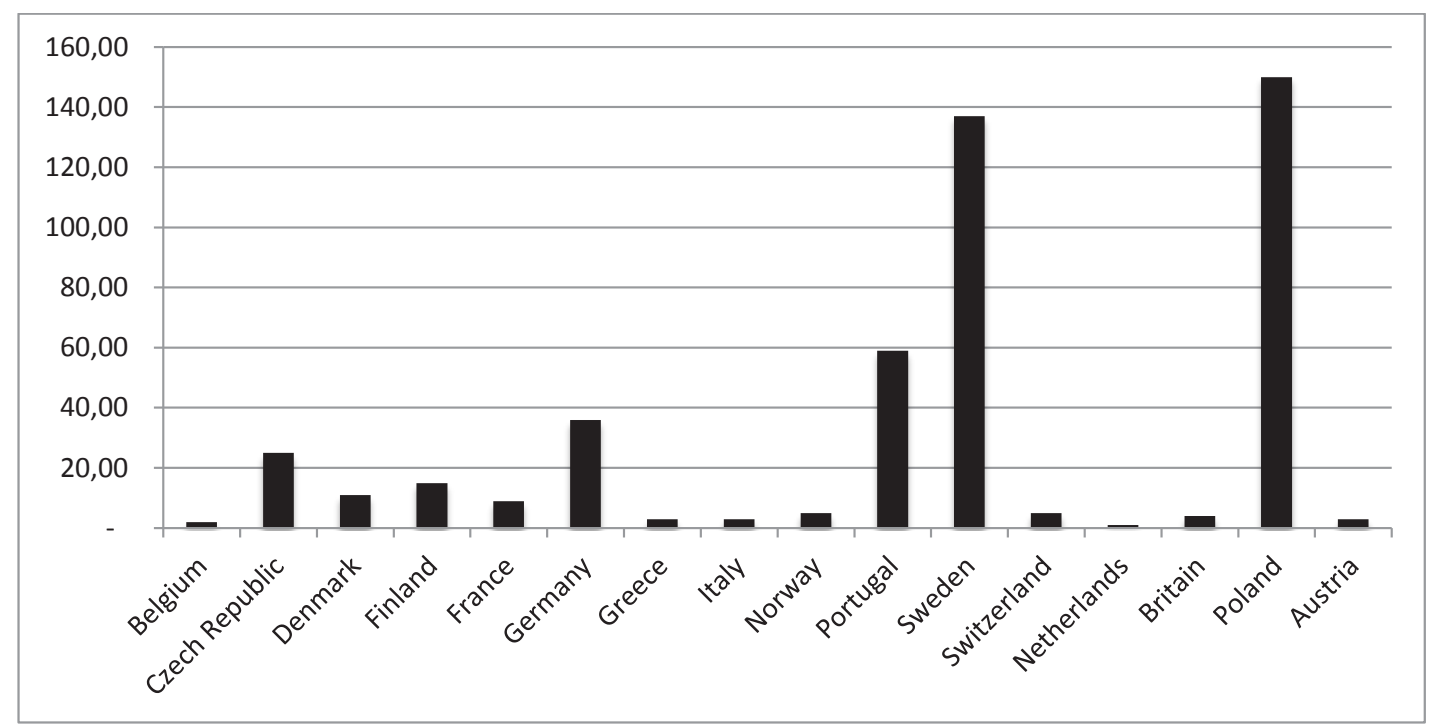

Figure 2. Growth rate of franchising in the EU member-countries in 2018

Source: European Franchise Federation, 2019 
have more chances to increase the competitiveness of the economy in all and take a favorable position in the international market. Moreover, franchising is the most democratic instrument of doing business, as developing its own franchise network the franchisor brings not only his brand and production methods but also high standards, which his goods correspond with, to new markets and territories. Also, it is worth noting that franchising is a very effective method of expanding sales networks in overseas markets since it is an active and very common way of doing business that is going to Ukraine from the European Union.

The most widespread in Ukraine is merchandise franchising - 181 offers, followed by service franchising 111 offers, business format - 90 and production 23 (Figure 3).

Among domestic franchises, 77 - service, 69 merchandise, 58 - business format and 10 - production franchises. Among foreign ones, the situation is somewhat different: 112 - merchandise, 34 - service, 32 - business format and 13 - production ones.

The exclusive rights to operate in the country or even in the region are also analyzed; with 118 franchisors of 405 franchises are willing to provide such rights to their franchisees. Among these 118 proposals, 89 are foreign, and only 29 are domestic ones. This is due to the fact that master franchises are usually used by the franchisor that goes to a new market.

Franchise fees have a fairly wide price range from its total absence to a fairly significant price of 100,000 dollars and more. The same applies to the investment while starting a business: from 20 dollars to over 1 million dollars. It is noteworthy that mostly there are no franchise fees in franchises of merchandise franchising, as the franchisor receives main income from the sales of their goods through franchisee shops and royalty payments.

The average cost of the analyzed franchises (a franchise fee) is 5,525 dollars, investment $-45,407$ dollars.
The investment capacity of all franchises for one business point (excluding a potential one) is 11,896,682 dollars, and with a franchise fee $13,322,098$ dollars.

Location requirements are often one of the main conditions of franchisors, due to their concern not only about income but also about the development and maintenance of the company's prestige as well as compliance with a business plan.

Retail stores, their own premises and offices are quite popular among the analyzed franchises, confirming the distribution by business categories. The following is a variety of locations and the franchisor's requirement frequency: the retail store -163 , own premises -96 , the office -86 , the restaurant -67 , booths -45 , shopping streets and shopping centers -13 , work at home -12 , the vehicle -11 .

Frequently, the franchisor offers several franchise packages that differ in many conditions, one of which is location. This is most commonly used in public catering when several formats of retail outlets, from a small vehicle to a restaurant, are offered.

Among 43 franchise categories in the market, there are the following franchises: retail trade -158 , catering -86 , training -20 , servicing -19 , delivery 17 , printing and design -11 , distribution -9 , travel and tourism -8 , financial services -8 , beauty -8 , promotion and advertising - 7 , entertainment and events -7 , production -7 , repair and maintenance -6 , food -4 , Internet services and communication -4 , sport and fitness -4 , health care and medicine -4 , chemical industry - 4, media - 4, children and infants - 3, electrical equipment -3 , cleaning -3 , vending -2 , legal services -2 , agriculture -2 , real estate agencies -1 , design and architecture - 1, recruitment - 1 , photography -1 , consulting services -1 , animals -1 .

The fact that the number of franchises in categories is larger than the franchises analyzed is because some offers have several packages, or one and the same franchise

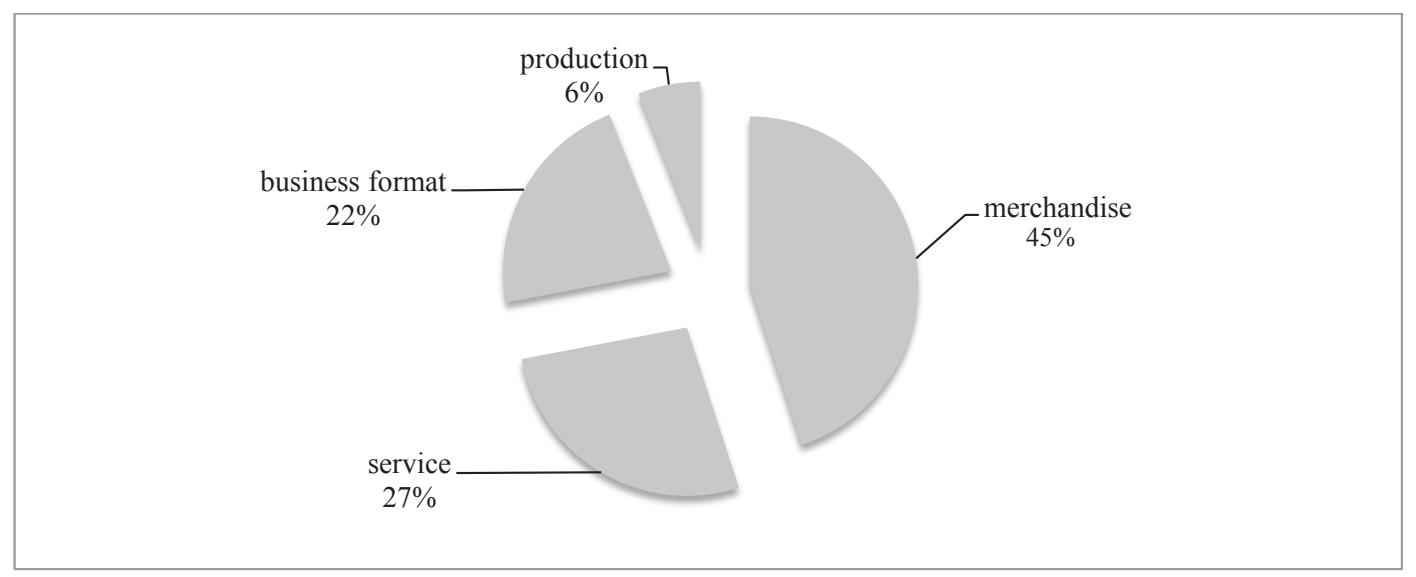

Figure 3. Types of franchises in Ukraine

Source: Asotsiatsiya franchayzynhu Ukrayiny 
belongs to several categories. The most common among Ukrainian franchises is public catering -58 , retail trade 55 , servicing - 11, delivery - 11 and studyingtraining -9 . The most common among foreign franchises is retail trade -103 , public catering - 28 , studying and training -11 , servicing -8 and printing and design -7 .

\section{The results of testing of factors affecting franchising development model}

In the franchising analysis, dependent variables can be represented by: size of a network, rate of franchise, royalty and rate of own franchise points etc.

Table 1

The main factors affecting the size of a franchising network development

\begin{tabular}{|l|c|c|c|}
\hline $\begin{array}{c}\text { Dependent variable - } \\
\text { size of a network }\end{array}$ & Model 1 & Model 2 & Model 3 \\
\hline Age & $\begin{array}{c}147,0664^{*} \\
(1,974938)\end{array}$ & $\begin{array}{c}206,1044^{* *} \\
(2,725401)\end{array}$ & \\
\hline Rate of franchise fees & $\begin{array}{c}0,248064^{* *} \\
(2,867457)\end{array}$ & & \\
\hline Investment level & & $0,013387^{*}$ & \\
\hline Royalty & & & $\begin{array}{c}72301,87^{* *} \\
(2,240383)\end{array}$ \\
\hline $\begin{array}{l}\text { Rate of own franchise } \\
\text { points }\end{array}$ & & & $\begin{array}{c}-457,3140 \\
(-0,083973)\end{array}$ \\
\hline
\end{tabular}

Source: made by the authors

Table 1 shows the values of coefficients and T-statistics (in brackets). ${ }^{*}$ means significance at alpha $=0.1,{ }^{* *}$ significance at alpha $=0.05$ and ${ }^{* * *}-$ significance at alpha $=0.01$.

The study shows that the size of a franchisor's network is affected by the network age (the number of years in the market). An additional year of operation in the market on average brings 147-206 additional network points. Networks with a higher investment level, a higher rate of franchise fees and royalty are also expanding more

Table 2

The main factors affecting the rate of franchise fees

\begin{tabular}{|l|c|c|c|c|}
\hline $\begin{array}{c}\text { Dependent } \\
\text { variable }- \\
\text { rate of } \\
\text { franchise } \\
\text { fees }\end{array}$ & Model 1 & Model 2 & Model 3 & Model 4 \\
\hline Age & $\begin{array}{l}314,8562^{* *} \\
(2,144314)\end{array}$ & $\begin{array}{c}239,2356 \\
(1,117504)\end{array}$ & & \\
\hline $\begin{array}{l}\text { Size of a } \\
\text { network }\end{array}$ & & & $\begin{array}{c}0,992251^{* * *} \\
(3,049694)\end{array}$ & $\begin{array}{c}1,394554 \\
(1,621134)\end{array}$ \\
\hline $\begin{array}{l}\text { Investment } \\
\text { level }\end{array}$ & $0,037849^{* *}$ & & $0,029793^{* *}$ & \\
\hline Royalty & $(2,586787)$ & $(2,115550)$ & \\
\hline
\end{tabular}

Source: made by the authors actively. Extra thousand dollar investment means a larger network size by 13 points, an additional 100 dollars of a franchise fee means a larger network size by 24 points, and additional $1 \%$ of royalty means a larger network size by 723 points. \% of their own points does not significantly affect the size of a franchise network.

Table 2 shows the values of coefficients and T-statistics (in brackets). * means significance at alpha $=0.1,{ }^{* *}$ significance at alpha $=0.05$ and ${ }^{* * *}-$ significance at alpha $=0.01$.

The amount of a franchise fee is affected by the network age (the number of years in the market). An additional year of work in the market assumes additional 239-314 dollars of a franchise fee. Networks with a higher investment and royalty rate have also a higher franchise fee. Additional required thousand dollars of investment involves a larger amount of a franchise fee by 29-37 dollars, and an additional 1 dollar of royalty provides a larger amount of a franchise fee by 15-18 dollars. Also, the amount of a franchise fee is affected by the size of the network itself. Each additional point allows increasing a franchise fee by 0.99-1.39 dollars.

Table 3

The main factors affecting the royalty in the franchise network (case 1)

\begin{tabular}{|l|c|c|}
\hline Dependent variable - royalty & Model 1 & Model 2 \\
\hline Size of a network & $\begin{array}{c}0,0000033^{* *} \\
(2,240383)\end{array}$ & \\
\hline Investment level & & $\begin{array}{c}0,000000178^{*} \\
(1,944827)\end{array}$ \\
\hline Rate of own franchise & $\begin{array}{c}-0,007555 \\
(-0,205473)\end{array}$ & $\begin{array}{c}-0,008259 \\
(-0,217953)\end{array}$ \\
\hline
\end{tabular}

Source: made by the authors

Table 3 shows the values of coefficients and T-statistics (in brackets). ${ }^{*}$ means significance at alpha $=0.1{ }^{* *}-$ significance at alpha $=0.05$ and ${ }^{* * *}-$ significance at alpha $=0.01$.

The amount of royalty (in \%) is affected by the network size. Additional thousand network points on average increase the royalty rate by $0.3 \%$. Thus, networks with a higher investment level have a higher royalty rate. Additional required 10 thousand dollars of investment means a larger royalty rate by $0.178 \%$.

Table 4

The main factors affecting the royalty in franchise network (case 2)

\begin{tabular}{|l|c|c|}
\hline Dependent variable - royalty & Model 1 & Model 2 \\
\hline Rate of franchise fees & & $\begin{array}{c}0,014109^{* *} \\
(2,304758)\end{array}$ \\
\hline Investment level & $\begin{array}{c}0,001649^{* * *} \\
(3,828943)\end{array}$ \\
\hline Age of a network & $-6,488691$ & $-4,717505$ \\
& $(-1,290835)$ & $(-0,782908)$ \\
\hline
\end{tabular}

Source: made by the authors 
Table 4 shows the values of coefficients and T-statistics (in brackets). * means significance at alpha $=0.1{ }^{* *}$ - significance at alpha $=0.05$ and ${ }^{* *}$ - significance at alpha $=0.01$.

Networks with a higher required investment level and a higher franchise fee have a higher royalty rate. Additional required 10 thousand dollars of investment includes a larger royalty rate by 16.49 dollars and the additional sum of 1,000 dollars of a franchise fee includes a larger royalty rate by 14,109 dollars.

\section{Conclusion}

Having analyzed the influence of various factors on the development of franchising in Ukraine, European countries and the USA, the authors can draw the following conclusions:

- the network age affects the franchisor's network size. That is, the greater the franchisor's age is, the more franchise points it has;

- the size of a franchise network is affected by the investment level, a franchise fee and royalty. With the increase of all these indicators, the network size grows, however, the percentage of own points have a little effect;
- according to the investment level, a franchise fee also increases according to the franchise network size;

- the amount of royalty depends on the investment level and the franchise network size.

Franchising is the most democratic tool for doing business, as developing their own franchise network, franchisors bring not only their own brands and production methods to new markets and territories but also high norms and standards that their products meet; franchising is one of the tools for the formation of innovative development of the global economy. The high popularity and considerable prevalence of franchising are determined by the fact that it offers real opportunities for the development of goods sales networks both in domestic and foreign markets, attracting relatively little money and most importantly for a small period of time.

Franchising opens up wide opportunities for the development of not only small and medium-sized businesses but also for the country's economy as a whole; therefore, further scientific developments should concern first of all the search for ways, methods and tools to attract new technologies and innovations, especially environmentally friendly ones.

\section{References:}

Asotsiatsiya franchayzynhu Ukrayiny [Franchising Association of Ukraine]. Retrieved from: http://www.franchising.org.ua (accessed 5 February 2019). (in Ukrainian)

Burnett, R. (2004). Law of International Business Transactions. 3rd ed. Sydney, 329 p.

Commission Regulation (EC) N 2790/1999 of 22 December 1999 on the application of Article 81(3) of the Treaty to categories of vertical agreements and concerted practices (1999). Vol. 42, L 336, pp. 21-25.

European Franchise Federation. Retrieved from: http://www.eff-franchise.com (accessed 3 April 2019).

International Franchising: The European Union (2018). Retrieved from: http://www.unh.edu/news/docs/ RCIF_EU2006.pdf (accessed 26 February 2019).

Ohinok, S. (2016). The Strategy of Entry of Franchise Networks from the EU into the Ukraine's Market. Handel wewnętrzny, 3(362), 228-238.

Reestr seti v Ukraine [Register of "Networks in Ukraine" in 2018]. Retrieved from: http://www.franchising.org.ua/ page/reestr_seti_v_ukraine (accessed 4 April 2019). (in Russian)

Stawicka, M. K. (2009). Franczyza - droga do sukcesu. Warszawa, 208 p.

Top 500 Franchises in Europe in 2015. Retrieved from: http://www.franchisedirect.co.uk/top500/ (accessed 5 February 2019).

Wynogradska, A. (2004). Komerciine pidpryemnytstwo: suchasnyi stan, strategii rozwytku [Commercial entrepreneurship: current state, development strategies]. Kyiv, 807 p. (in Ukrainian)

Ziółkowska, M. J. (2010). Franczyza Nowoczesny Model Rozwoju Biznesu. Warszawa, 228 p. 